\title{
Distribution extension of Stenocercus squarrosus Nogueira and Rodrigues, 2006 (Reptilia, Squamata, Tropiduridae) in Northeastern Brazil
}

\author{
Samuel Cardozo Ribeiro \\ Igor Joventino Roberto ${ }^{2}$ \\ Débora Lima Sales ${ }^{1}$ \\ Waltécio de Oliveira Almeida ${ }^{1 *}$ \\ ${ }^{1}$ Universidade Regional do Cariri, Departamento de Química Biológica \\ R. Cel. Antônio Luiz, 1161, CEP 63105-000, Crato - CE, Brazil \\ ${ }^{2}$ AQUASIS - Associação de Pesquisa e Preservação de Ecossistemas Aquáticos \\ Programa de Conservação da Biodiversidade \\ Praia de Iparana s/n, CEP 61627-010, Caucaia - CE, Brazil \\ *Corresponding author \\ waltecio@gmail.com
}

\section{Resumo}

Extensão da distribuição de Stenocercus squarrosus Nogueira and Rodrigues, 2006 (Reptilia, Squamata, Tropiduridae) no nordeste do Brasil. Lagartos do gênero Stenocercus Duméril \& Bibron, 1837 são amplamente distribuídos na América do Sul, podendo ocorrer tanto em terras baixas quanto em elevadas altitudes. Stenocercus squarrosus foi recentemente descrita para o estado do Piauí, na região do Parque Nacional Serra das Confusões, sendo até então considerada restrita. Nós relatamos aqui o primeiro registro de ocorrência dessa espécie no estado do Ceará, ocorrendo em uma área de altitude no município de Santana do Cariri, estado do Ceará, dentro dos limites da Área de Proteção Ambiental da Chapada do Araripe, sendo este o primeiro registro do gênero para o estado, ampliando a distribuição da espécie em cerca de $460 \mathrm{~km}$ em linha reta, sentido nordeste. Este registro reforça a importância de conservação da área, indicando a necessidade de mais estudos investigativos de fauna no local, sobretudo em áreas de Carrasco e Cerrado, as quais têm sido pobremente estudadas no Ceará.

Unitermos: Stenocercus squarrosus, distribuição, Ceará, Carrasco, Cerrado

\section{Abstract}

Lizards of the genus Stenocercus Duméril and Bibron, 1837 are widely distributed throughout South America, being found both in lowlands and at high altitudes. Stenocercus squarrosus was recently described from, and is supposed to, be restricted to the region of Serra das Confusões National Park, Piauí State, Brazil. We here report the first record of this species in Ceará State, from a reasonably high altitudinal area in the municipality of Santana do Cariri, Ceará State, within the limits of the Chapada do Araripe Environmental Protection Area, and it is the first record of this genus for the state, which represents an increase of approximately $460 \mathrm{~km}$ (airline) 
northeast of the previously known distribution of this species. Our finding reinforces the importance of conserving that area and indicates the necessity of additional inventories of the local fauna, especially in areas of Carrasco and Cerrado vegetation poorly sampled in Ceará.

Key words: Stenocercus squarrosus, distribution, Ceará, Carrasco, Cerrado

Lizards of the genus Stenocercus Duméril and Bibron, 1837 are widely distributed in South America (Torres-Carvajal et al., 2006). The genera comprises 61 species that occur at elevations between $0-4000 \mathrm{~m}$ in the Andes and adjacent lowland areas, from northern Venezuela and Colombia to central Argentina, with some species being found in the Atlantic lowlands between southern Brazil and central Argentina, and in Northeastern Brazil (Torres-Carvajal, 2007).

Stenocercus squarrosus was recently described from the southern region of the Serra das Confusões National Park (09 $13^{\prime}$ S and $\left.43^{\circ} 29^{\prime} \mathrm{W}\right)$, Piauí State, Brazil, an ecotonal area between cerrado and caatinga vegetation types (Nogueira and Rodrigues, 2006). This species is unique among all other congenerics except $S$. dumerilii (Steindachner, 1867), S. quinarius Nogueira and Rodrigues, 2006, and S. tricristatus (Duméril, 1851) by having a pyramidal head, as well as enlarged, dorsally-projected posterior supraciliaries. Stenocercus squarrosus differs these other species by the combination of the following characteristics: presence of a short tail 0.8-0.9 times the Snout-Vent Length (SVL), presence of proeminent vertebral, paravertebral, and lateral crests, and 46-53 midbody scales (Nogueira and Rodrigues, 2006; Torres-Carvajal, 2007).

A specimen of $S$. squarrosus (Figure 1) was collected while it was foraging near a cassava crop (Manihot esculenta) manually by a local resident, Jefferson Luis Gonçalves, on the morning of February 17, 2008, in the Serra de São Gonçalo mountain range ( $07^{\circ} 10^{\prime} \mathrm{S}$ and $39^{\circ} 51^{\prime} \mathrm{W}$; elevation $\sim 791 \mathrm{~m}$ ), inside the boundaries of the Chapada do Araripe Environmental Protection Area (APA), in the municipality of Santana do Cariri, Ceará State, Northeastern Brazil. The area consists of a mosaic of phytophysiognomies of carrasco, cerrado, and caatinga vegetation, with extensive and secondary forests. The specimen was fixed in $10 \%$ formalin, conserved in 70\% ethanol (Aurichio and Salmão, 2002), measuremented in mm, and deposited in the herpetological collection of the Universidade Regional do Cariri/ URCA (LZ-URCA 459).

This specimen had the following morphometric and meristic characteristics: adult male 78.9 SVL, 65.1 tail length, 16.8 head width, 20.5 head length, 14.3 head height, 33.3 arm length, 41.1 leg length, 48 scales around midbody, 27 transverse ventral rows, 13 dorsal rows, eight lateral rows, 25 scales in vertebral crest, 18 lamellae in the 4th toe, 14 lamellae in the 4th finger, 43 longitudinal caudal rows, five internasal scales, keeled scales on the top of the head, an enlarged, prominent, pointed scale immediately posterior to the supraciliaries, gulars and ventrals distinctly keeled, mite pockets absent, dorsal coloration uniform, four narrow transverse dark brown dorsal bands, with a distinctive dark blotch above insertion of forelimbs, and a faint vertical dark band across the eyes, two dark brown bands on the posterior limbs, and dark coloration on the elbows.

This is the first record of S. squarrosus for Ceará State and it represents a significant range extension, ca. $460 \mathrm{~km}$ (airline) northeast of previously known range only from its type locality (Nogueira and Rodrigues, 2006). The discovery of this species in the Chapada do Araripe Environmental Protection Area reinforces the importance of this conservation area, and indicates the need for additional studies in the region.

\section{Acknowledgments}

The authors would like to thank FUNCAP-Fundação Cearense de Apoio ao Desenvolvimento Científico e Tecnológico (Process number 9913/06 - Contract 000600/2006), Brazilian Institute for the Environment and Natural Resources (IBAMA) for permission to collect samples from protected areas (066/06-COFAN IBAMA/ RAN/ 02007.001009/04-37), and Roy Funch (UEFS) for translation, as well as for suggestions and revision of the English version of the manuscript. 


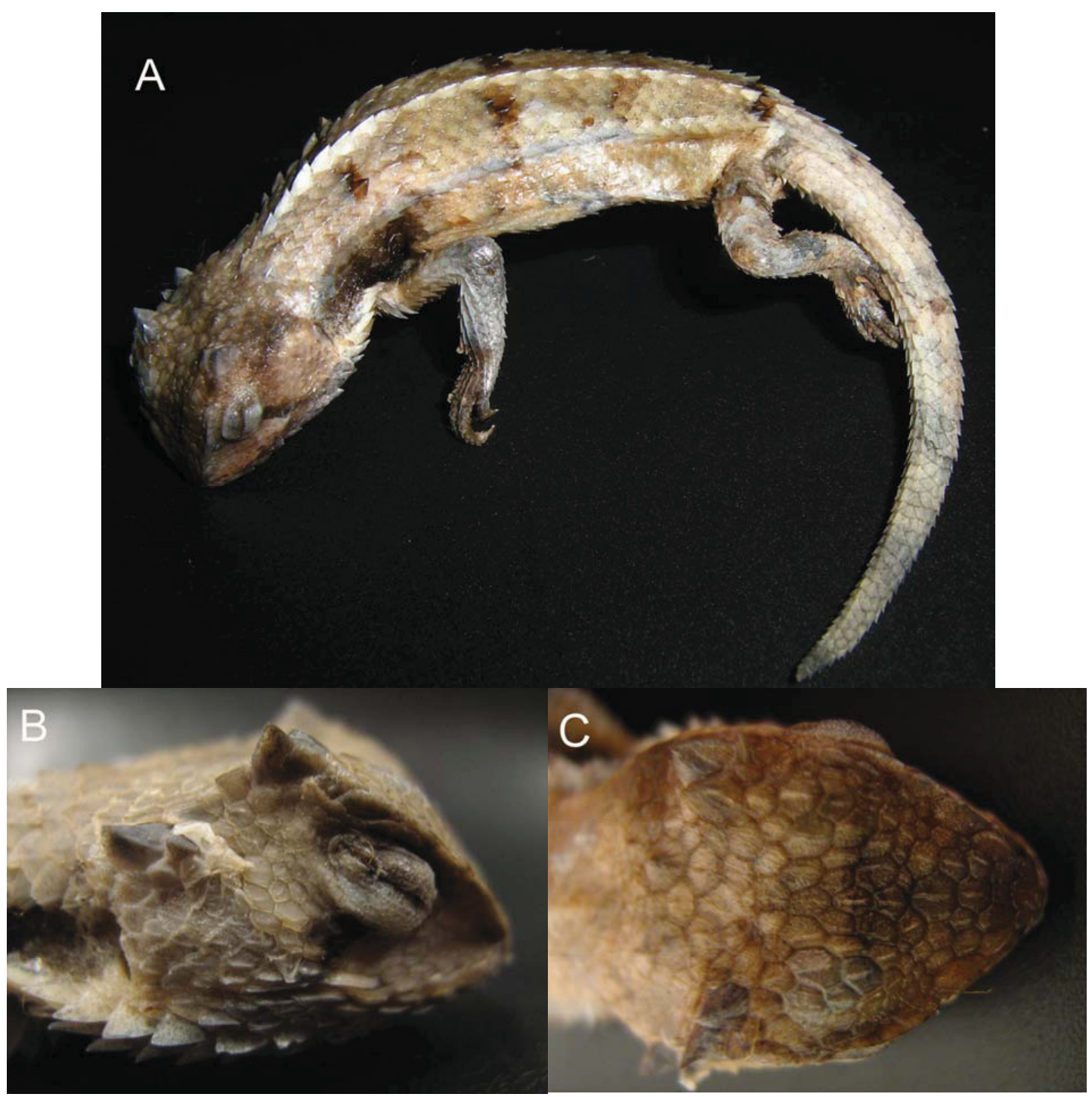

FIGURE 1: General view (A), and lateral (B) and dorsal (C) details of the head of a male specimen of S. squarrosus (LZ-URCA 459) from Chapada do araripe Environmental Protection Area, Ceará, Brazil.

\section{References}

Aurichio, P.; Salomão, M. G (Orgs). 2002. Técnicas de coleta e preparação de vertebrados para fins científicos e didáticos. Instituto Pau Brasil de História Natural, São Paulo, Brazil, 348pp.

Nogueira, C.; Rodrigues, M. T. 2006. The genus Stenocercus (Squamata: Tropiduridae) in extra-Amazonian Brazil, with the description of two new species. South American Journal of Herpetology, 1 (3): 149-165.
Torres-Carvajal, O. 2007. A taxonomic revision of South American Stenocercus (Squamata: Iguania) lizards. Herpetological Monographs, 21: 76-178.

Torres-Carvajal, O.; Schulte, J. A.; Cadle, J. E. 2006. Phylogenetic relationships of South American lizards of the genus Stenocercus (Squamata: Iguania): a new approach using a general mixture model for gene sequence data. Molecular Phylogenetics and Evolution, 39: 171-185. 